Bangladesh J. Bot. 49(1): 21-27, 2020 (March)

\title{
PHYTOREMEDIATION OF SELECTED HEAVY METALS USING BRYOPHYLLUM DAIGREMONTIANUM (RAYM-HAMET \& H. PERRIER) A. BERGER
}

\author{
Hanif Khan ${ }^{1}$, Muhammad Saleem Khan, Muhammad Anwar Sajad, Haroon Khan ${ }^{2}$, \\ MUhammad Ihsan ${ }^{3}$, Irfan Ullah ${ }^{1}, Z_{\text {ahid }} \mathrm{KhaN}^{4}$ and UMAR ZeB $^{* 1}$ \\ Department of Botany, Islamia College Peshawar (A Public Sector University)-25120, \\ Khyber Pakhtunkhwa, Pakistan
}

Keywords: Phytoremediation, Phytoextraction, Phytostabilization

\begin{abstract}
Heavy metals are hazardous to plants as well as to humans. The purpose of the current work was to explore the phytoextraction potential of B. daigremontianum (Raym.-Hamet \& H. Perrier) A. Berger for the uptake of cadmium $(\mathrm{Cd})$, nickel $(\mathrm{Ni})$ and zinc $(\mathrm{Zn})$ through roots, leaves and stem. B. daigremontianum grown in the contaminated soil showed relatively higher values for the uptake of $\mathrm{Cd}, \mathrm{Ni}$ and $\mathrm{Zn}$ as compared to those grown in control soil. However, the accumulation rate of heavy metals was arranged in the order: $\mathrm{Zn}$, $\mathrm{Ni}$ and $\mathrm{Cd}$ in root $>$ leaf $>$ stem. There was a significant difference at $\mathrm{p}<0.05$ from their relevant control. Bioconcentration factors (BCF root) values clearly show the differences of heavy metals in control and contaminated plants which were 1.0106, 0.8306 and 0.6652 , indicating the uptake in the order $\mathrm{Zn}>\mathrm{Ni}>\mathrm{Cd}$. B. daigremontianum used for the Phytostabilization of $\mathrm{Zn}$ because the $\mathrm{BCF}$ value of the plant for this metal is greater than one.
\end{abstract}

\section{Introduction}

Phytoremediation mean to remove or restoring balance because plant-based remediation of pollutants from soil (Ali et al. 2013). In this technology, green plants are used for the cleaning of contaminated soil and water. Botano-remediation, vegetative remediation, green remediation and agro-remediation also termed for phytoremediation (Agbontalor 2007). In the past few years, the advanced technology of phytoremediation that can potentially address the problems of contaminated agricultural land or more intensely polluted areas are affected by urban or industrial activities. However, phytoremediation processes rely on the ability of plants to take up and metabolize pollutants to high or less toxic substances. In addition, the uptake, accumulation and degradation of contaminants vary among plants. Meanwhile, phytoremediation is required by plants for growth, the ability to tolerate and accumulate contaminants, increase rooting zone and potential to transpire groundwater. Furthermore, the plants used in phytoremediation should not only accumulate, degrade or volatilize the contaminants but should also grow quickly in a wild range of different conditions (Pivertz and Bruce 2001).

Generally, for the purpose of decontamination of metals, various physical and chemical methods are employed which have certain limitation like demanding labour, high cost, disturbance of near-natural microflora and permanent changes in soil properties. In addition, substitute green solution for removal of heavy metals pollution is phytoremediation which is an advanced technique (Ali et al. 2013). Furthermore, in less developed countries remediation technology, is

*Author for correspondence: <umar02mkd@gmail.com>. Key Laboratory of Resource Biology and Biotechnology in Western China, Ministry of Education, College of Life Sciences, Northwest University, Xi'an 710069, China. ${ }^{2}$ Department of Weed Science, The University of Agriculture Peshawar. ${ }^{3}$ School of Urban and Environmental Sciences, Northwest University, China. ${ }^{4}$ Shaanxi Key Laboratory for Animal Conservation, Northwest University, Xi' an 710069, China. ${ }^{5}$ University of Malakand Chakdara, Dir(L) Khyber Pakhtunkhwa. 
more suitable as they are less costly (Pivertz and Bruce 2001). Heavy metals are categorized as essential and non-essential regarding their role in the biological system. Some essential heavy metals required in a small amount for living organisms while non-essential heavy metals are not required for the living organisms even in very low concentration (Gohre and Paszkowski 2006). To increase the productivity of agriculture, necessary herbicides, pesticides and fertilizers are used. The accumulation of these chemicals in the soil containing heavy metals and other toxic materials when used in excess create environmental problems (Sahibin et al. 2002). For example, the concentration of $\mathrm{Zn}, \mathrm{Cu}$, As and $\mathrm{Cd}$ increases when phosphate fertilizers are applied to the agriculture soil (Zarcinas et al. 2004).

Furthermore, the fuel production, smelting process, mining, military operations and coal combustion are sources of metal pollution (Shen et al. 2000). The industrial and sewage wastes used for irrigation are additional sources of heavy metals (Bridge 2004). Techniques of phytoremediation may be categorized as phytodegradation, phytoextraction, phytofiltration, phytovolatilization and phytostabilization (Alkorta et al. 2004). In phytoextraction, plant roots absorb, translocate and store toxins along with water and other essential nutrients (Lasat 2002). Plant species basically adapted to grow in soil containing a large number of heavy metals are called metallophytes (Sheoran et al. 2010). The soil containing a large number of heavy metals are known as metalliferous soils and plants growing in these sites are resistant to heavy metals (Ernst 2000). A most interesting group among metallophytes is hyperaccumulators, plants showing extraordinary heavy metal accumulation capability (Van der Ent et al. 2013). The present study was designed to investigate the intake and concentration of cadmium, nickel and zinc in the roots, stem and leaves of the Bryophyllum daigremontianum (Raym.-Hamet \& H. Perrier) A. Berger.

\section{Materials and Methods}

The seedlings of the plant, B. daigremontianum were obtained from Chakdara, Department of Botany, University of Malakand, Pakistan. The experiment was conducted in pots Department of Botany, Islamia College University Peshawar, Pakistan.

Soil $(6.5 \mathrm{~kg})$ was put into each pot while the first soil passed through $1 \mathrm{~mm}$ sieve. Pots were divided into four groups i.e. one control group into which no metals were added and three groups into which $\mathrm{Cd}, \mathrm{Ni}$ and $\mathrm{Zn}$ were added. As a water-soluble salt, these metals were added to the soil in the form of their aqueous solutions. The $100 \mathrm{ppm}$ cadmium was added to the soil as $\mathrm{CdCl}_{2} \cdot 2^{1 / 2}$ $\mathrm{H} 2 \mathrm{O}, \mathrm{Ni}$ as $\mathrm{NiCl} 2.6 \mathrm{H} 2 \mathrm{O}$ and $\mathrm{Zn}$ as $\mathrm{ZnSO} 4.7 \mathrm{H} 2 \mathrm{O}$. Ten seedlings of $\mathrm{B}$. daigremontianum were grown in each pot. In the same pots, the seedlings were allowed to grow until maturity. The mature plants were depoted and separated into leaves, stem and roots.

Background concentrations of heavy metals $(\mathrm{Cd}, \mathrm{Ni}$ and $\mathrm{Zn})$ were analyzed in the soil and water. Heavy metals in the soil were determined according to Shriadah (1999). Soil sample (5 g) was taken in a $100 \mathrm{ml}$ beaker. The $3 \mathrm{ml}$ of $30 \% \mathrm{H}_{2} \mathrm{O}_{2}$ was added to the beaker and kept them undisturbed for one hr. The beaker was placed on the hot plate for two hrs and $75 \mathrm{ml}$ of $0.5 \mathrm{M} \mathrm{HCl}$ solution was added to the beaker. The digest was filtered through Whatman filter paper. For the analysis of heavy metals ( $\mathrm{Cd}, \mathrm{Ni}$ and $\mathrm{Zn}$ ), the filtrate was then checked under atomic absorption spectrometry (AAS). The analysis was conducted in replicates and results were shown as mean.

Each plant part was washed carefully with tap water in order to remove soil particles. Clean parts were dried and then placed in an oven for $24 \mathrm{hrs}$ at $105^{\circ} \mathrm{C}$. According to Awofolu (2005) the samples were digested in $100 \mathrm{ml}$ beaker. A $0.5 \mathrm{~g}$ sample of plant part was taken in a beaker. Two $\mathrm{ml}$ of $\mathrm{HCLO}_{4}$ and $5 \mathrm{ml}$ concentrated $(65 \%) \mathrm{HNO}_{3}$ were added and heated on a hot plate until plant parts were digested. Before filtration, through the Whatman filter paper, the digest was allowed to cool. In a volumetric flask of $50 \mathrm{ml}$, the filtrate was collected and diluted up to $50 \mathrm{ml}$ with distilled 
water. For the analysis of heavy metals $(\mathrm{Cd}, \mathrm{Ni}$ and $\mathrm{Zn})$, the filtrate was checked under AAS (AAS-700, Perkin-Elmer, USA) using acetylene/air as a gas mixture. The $228.89 \mathrm{~nm}, 283.3 \mathrm{~nm}$ and $213.9 \mathrm{~nm}$ were the lamp wavelength for $\mathrm{Cd}, \mathrm{Ni}$ and $\mathrm{Zn}$, respectively. Each experiment was repeated in triplicate. The mean results were calculated.

Uptake efficiency and accumulation of heavy metals in different parts indicated the bioconcentration factor (BCF). It is the percentage calculation of heavy metal accumulation in different parts as compared to that in the soil. It was calculated following Zhuang et al. (2007). Bioconcentraion factor $(\mathrm{BCF})=$ Metal concentration in parts of a whole plant/initial concentration of metal in soil was calculated.

The efficiency of plants to accumulate and translocate heavy metals from root to shoots indicated the translocation factor (TF). The accumulation of heavy metals in stem and leaves to that of roots were calculated in TF. It is calculated as according to the method of Padmavathiamma and $\mathrm{Li}$ (2007).

Translocation factor $(\mathrm{TF})=$ Metal concentration in aerial parts/Metal concentration in roots. All results were shown in mean \pm SD. ANOVA were used for the data analysis.

\section{Results and Discussion}

The concentration of $\mathrm{Cd}$ in different parts of B. daigremontianum (Fig. 1), the concentration of $\mathrm{Cd}$ in plant parts was in the order: roots > leaves > stem. However, the concentrations of $\mathrm{Cd}$ in these parts were $8.433333,5.246667$ and $2.866667 \mathrm{mg} / \mathrm{kg}$, respectively which increased to $62.83333,38.43333$ and $16.63333 \mathrm{mg} / \mathrm{kg}$ when $\mathrm{Cd}$ was added to the soil (Table 1). The highest concentration of cadmium accumulate was found in roots. This revealed that roots were more favourable for the absorption of cadmium. In addition, this observation is in line with the finding of Zhang et al. (2009). As indicated by Smical et al. (2008), the root is the most important part which absorbs and eliminates heavy metals in an excess amount.

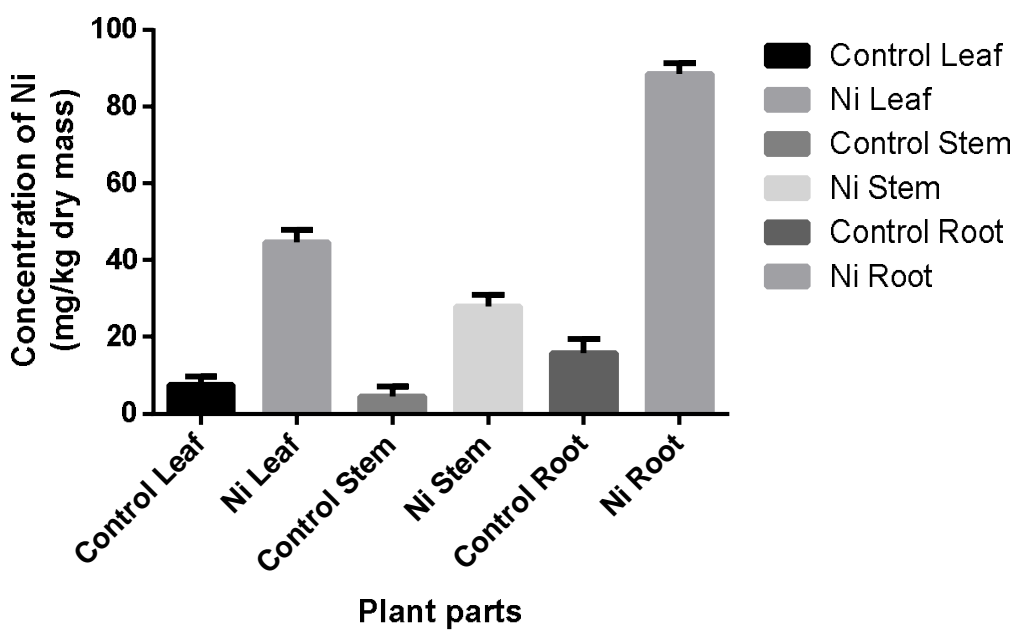

Fig. 1. Phytoextraction potential of $B$. daigremontianum grown in control and $\mathrm{Cd}$ contaminated soil. Error bars show standard error.

The concentration of $\mathrm{Ni}$ in different parts of B. daigremontianum is presented in (Fig. 2) The concentration of $\mathrm{Ni}$ in plant parts were in the order: roots > leaves $>$ stem. The concentrations of $\mathrm{Ni}$ in these parts were $15.73333,7.466667$ and $4.506667 \mathrm{mg} / \mathrm{kg}$, respectively which increased to 
$88.5,44.59667$ and $28.03333 \mathrm{mg} / \mathrm{kg}$ when $\mathrm{Ni}$ was added to the soil (Table 1). The highest concentration of $\mathrm{Ni}$ accumulated in roots. Furthermore, these findings coincide with the findings of many scientists (Wang and Chen 2009, Rahman and Hasegawa 2011, Huang et al. 2013) who recorded the highest concentration of $\mathrm{Ni}$ in roots of Amaranthus hybridus followed by leaves and stem.

Table 1. Concentration of $\mathrm{Cd}$, $\mathrm{Ni}$ and $\mathrm{Zn}$ in roots, stem and leaves.

\begin{tabular}{llll}
\hline \multicolumn{4}{c}{ Concentration of Cd, Ni and Zn } \\
\hline Metals & Root & Leaves & Stem \\
\hline $\mathrm{Cd}$ & 62.83333 & 38.43333 & 16.63333 \\
$\mathrm{Ni}$ & 88.5 & 44.59667 & 28.03333 \\
$\mathrm{Zn}$ & 105.666 & 64.12 & 34.69 \\
\hline
\end{tabular}

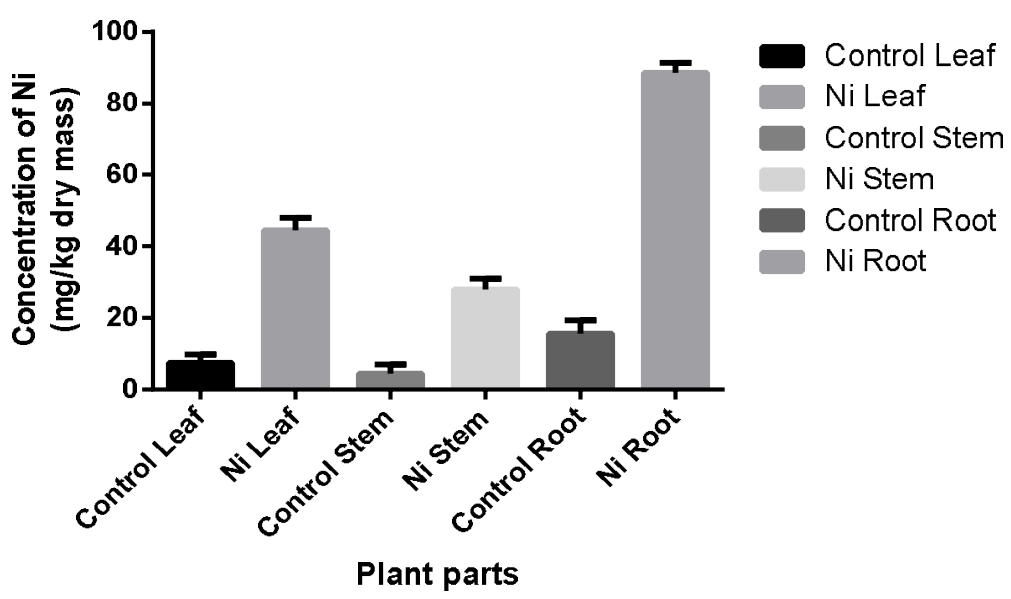

Fig. 2. Phytoextraction potential of B. daigremontianum grown in control and $\mathrm{Ni}$ contaminated soil. Error bars show standard error.

The concentration of $\mathrm{Zn}$ in different parts of B. daigremontianum is presented in (Fig. 3). The concentration of $\mathrm{Zn}$ in plant parts was in the order: roots > leaves > stem. The concentrations of $\mathrm{Zn}$ in these parts were $42.63333,28.5$ and $15.8 \mathrm{mg} / \mathrm{kg}$, respectively which increased to 105.666 , 64.12 and $34.69 \mathrm{mg} / \mathrm{kg}$ when $\mathrm{Zn}$ was added to the soil (Table 1). The highest concentration of $\mathrm{Ni}$ was found to accumulate in roots. Peralta et al. (2001) studied that alfalfa accumulated more zinc in their roots than other metals. It is guessed that zinc can act as a supplement for nutrient, which could clarify the higher mass accumulation when grown in soil treated with $\mathrm{Zn}$. The number of Bioconcentration factor for the selected heavy metals absorbed by B. daigremontianum are presented in the results of (Table 1). Results are based on the total soil concentrations (background concentrations + concentrations added to soil). BCF root values were $0.6652,0.8306$ and 1.0106 for cadmium, nickel and zinc, respectively. These values show that B. daigremontianum successfully removed the $\mathrm{Zn}$ from the contaminated soil because BCF value for $\mathrm{Zn}$ is greater than one. 
Translocation factor (TCF) for the selected heavy metals absorbed by B. daigremontianum (Table 2). TCF leaves values recorded are $0.6129,0.4988$ and 0.6273 for cadmium, nickel and zinc, respectively, these values were less than 1 for all. This is generally a limitation encountered in phytoremediation of heavy metals (Ali et al. 2013). According to Turan and Esringu (2007), due to the restriction of internal transport of $\mathrm{Ni}, \mathrm{Zn}$ and $\mathrm{Cu}$ from roots to shoot resulting in accumulation in roots, so there is a big difference between BCF and TF concentration.

Table 2. Translocation factors of B. daigremontianum for $\mathrm{Cd}$, $\mathrm{Ni}$ and $\mathrm{Zn}$.

\begin{tabular}{lcccccc}
\hline \multirow{2}{*}{ Metals } & \multicolumn{2}{c}{ Metal concentration in soil $(\mathrm{mg} / \mathrm{kg})$} & & \multicolumn{2}{c}{ TF of shoots } \\
\cline { 2 - 3 } \cline { 6 - 7 } & $\begin{array}{c}\text { Background } \\
\text { concentration }\end{array}$ & $\begin{array}{c}\text { Concentration } \\
\text { added to soil }\end{array}$ & $\begin{array}{c}\text { Total } \\
\text { concentration }\end{array}$ & & TF stem & TF leaves \\
\hline $\mathrm{Cd}$ & 7.1333 & 100 & 107.1333 & & 0.2736 & 0.6129 \\
$\mathrm{Ni}$ & 25.4733 & 100 & 125.4733 & & 0.3121 & 0.4988 \\
$\mathrm{Zn}$ & 46.7733 & 100 & 146.7733 & & 0.3419 & 0.6273 \\
\hline
\end{tabular}

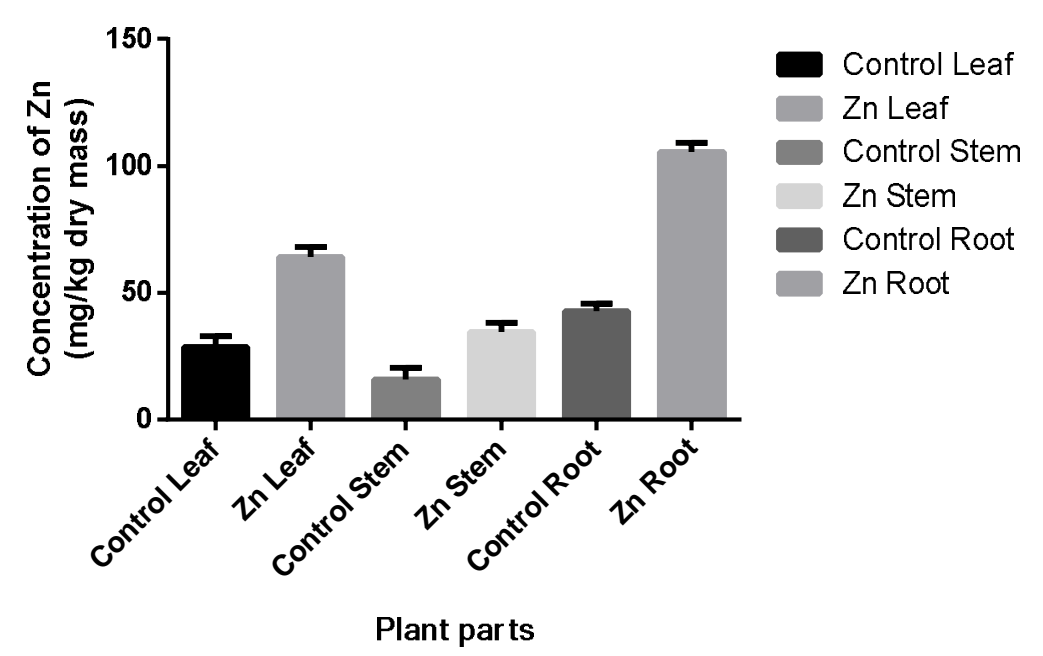

Fig. 3. Phytoextraction potential of B. daigremontianum grown in control and $\mathrm{Zn}$ contaminated soil. Error bars show standard error.

Table 3. Bioconcentration factors of B. daigremontianum for $\mathrm{Cd}, \mathrm{Ni}$ and $\mathrm{Zn}$.

\begin{tabular}{|c|c|c|c|c|c|c|}
\hline \multirow[b]{2}{*}{ Metals } & \multicolumn{3}{|c|}{ Metal concentration in soil (mg/kg) } & \multicolumn{3}{|c|}{$\mathrm{BCF}$ of harvested tissues } \\
\hline & $\begin{array}{l}\text { Background } \\
\text { concentration }\end{array}$ & $\begin{array}{l}\text { Conc. added } \\
\text { to soil }\end{array}$ & Total conc. & BCF root & $\begin{array}{c}\mathrm{BCF} \\
\text { leaves }\end{array}$ & BCF stem \\
\hline $\mathrm{Cd}$ & 7.1333 & 100 & 107.1333 & 0.6652 & 0.4077 & 0.1820 \\
\hline $\mathrm{Ni}$ & 25.4733 & 100 & 125.4733 & 0.8306 & 0.4149 & 0.2617 \\
\hline $\mathrm{Zn}$ & 46.7733 & 100 & 146.7733 & 1.0106 & 0.6312 & 0.344 \\
\hline
\end{tabular}


The present study showed heavy metal accumulation in roots, stem and leaves of $B$. daigremontianum which had the highest uptake capacity for $\mathrm{Zn}$ followed by $\mathrm{Ni}$ and $\mathrm{Cd}$. This is evident from the concentration difference of heavy metals between control and experimental plant. Roots of $B$. daigremontianum are more capable for absorption of $\mathrm{Zn}$ among the selected heavy metals as compared to leaves and stem as evident from the bioconcentration factor which were 0.6652, 0.8306 and 1.0106 for $\mathrm{Zn}, \mathrm{Ni}$ and $\mathrm{Cd}$ (Table 3). However, the translocations of these heavy metals were limited to the aerial parts as seen from translocation factor which were 0.6129 , 0.4988 and 0.6273 (Table 2). The order of metal accumulation in plants parts were $\mathrm{Cd}$ in root $>$ leaf $>$ stem, $\mathrm{Ni}$ in root $>$ leaf $>$ stem, $\mathrm{Zn}$ in root $>$ leaf $>$ stem. B. daigremontianum showed a significant difference at $\mathrm{p}<0.05$.

\section{References}

Agbontalor R 2007. Phytoremediation: an environmentally sound technology for pollution prevention, control and remediation in developing countries. Educ. Res. Rev. 2(7): 151-156.

Ali H, Khan E and Sajad MA 2013. Phytoremediation of heavy metals, concepts and applications. Chemosphere 91(7): 869-881.

Alkorta I, Hernandez JA, Becerril JM, Amezaga I, Albizu I and Garbisu C 2004. Recent findings on the phytoremediation of soils contaminated with environmentally toxic heavy metals and metalloids such as zinc, cadmium, lead, and arsenic. Rev Environ. Sci. Bio. 3(1): 71-90.

Awofolu OR 2005. A survey of trace metals in vegetation, soil and lower animal along some selected major roads in metropolitan city of Lagos. Environ. Monit. Assess. 105(1-3): 431-447.

Bridge G 2004. Contested terrain: mining and the environment. Annu. Rev. Environ. Resour. 29: 205-259.

Ernst WH 2000. Evolution of metal hyperaccumulation and phytoremediation hype. New Phytol. 146(3): 357-358.

Gohre V and Paszkowski U 2006. Contribution of the arbuscular mycorrhizal symbiosis to heavy metal Phytoremediation. Planta. 223(6): 1115-1122.

Huang L, Zhuo J, Guo W, Spencer RG, Zhang Z and Xu J 2013. Tracing organic matter removal in polluted coastal waters via floating bed Phytoremediation. Mar. Pollut. Bull. 71(1-2) 74-82.

Islam MS, Hossain M, Nasly MA and Sobahan MA 2013. Effect of industrial pollution on the spatial variation of surface water quality. Amer. J. Environ. Sci. 9(2): 120-129.

Lasat MM 2002. Phytoextraction of toxic metals. J. Environ. Qual. 31(1): 109-120.

Padmavathiamma PK and Li LY 2007. Phytoremediation technology: hyperaccumulation metals in plants. Water Air Soil Pollut. 184(1-4): 105-126.

Peralta JR, Gardea-Torresdey JL, Tiemann KJ, Gomez E, Arteaga S, Rascon E and Parsons JG 2001. Uptake and effects of five heavy metals on seed germination and plant growth in alfalfa (Medicago sativa L.). Bull. Environ. Contam. Toxicol. 66(6): 727-734.

Pivertz EB and Bruce 2001. Phytoremediation of Contaminated Soil and Ground Water at Hazardous Waste Sites. Environmental Research Services Corporation. EPA/540/S-01/500.

Rahman MA and Hasegawa H 2011. Aquatic arsenic: phytoremediation using floating macrophytes. Chemosphere 83(5): 633-646.

Sahibin AR, Zulfahmi AR, Lai KM, Errol P and Talib ML 2002. Heavy metals content of soil under vegetables cultivation in Cameron highland. In Proceedings of the Regional Symposium on Environment and Natural Resources. Kuala Lumpur, Malaysia. 1: 660-667.

Shen ZG, Li XD, Wang CC, Chen HM and Chua H 2000. Lead phytoextraction from contaminated soil with high-biomass plant species. J. Environ. Qual. 31(6): 1893-1900.

Sheoran V, Sheoran AS and Poonia P 2010. Role of hyperaccumulators in phytoextraction of metals from contaminated mining sites. Crit. Rev. Env. Sci. Tec. 41(2): 168-214.

Shriadah MM 1999. Heavy metals in mangrove sediments of United Arab Emirates shoreline (Arabian Gulf). Water Air Soil Pollut. 116(3-4): 523-534. 
Smical AI, Hotea V, Oros V, Juhasz J and Pop E 2008. Studies on transfer and bioaccumulation of heavy metals from soil into lettuce. Environ. Eng. Manag. J. 7(5): 609-615.

Turan M and Esringu A 2007. Phytoremediation based on canola (Brassica napus L.) and Indian mustard (Brassica juncea L.) planted on spiked soil by aliquot amount of $\mathrm{Cd}, \mathrm{Cu}, \mathrm{Pb}$, and $\mathrm{Zn}$. Plant Soil Environ. 53(1): 7.

Van der Ent A, Baker AJ, Reeves RD, Pollard AJ and Schat H 2013. Hyperaccumulators of metal and metalloid trace elements: facts and fiction. Plant Soil 362(1-2): 319-334.

Wang J and Chen C 2009. Biosorbents for heavy metals removal and their future. Biotechnol. Adv. 27(2): 195-226.

Zarcinas BA, Ishak CF, McLaughlin MJ and Cozens G 2004. Heavy metals in soils and crops in Southeast Asia. Environ. Geochem. Hlth. 26(4): 343-357.

Zhang H, Dang Z, Zheng LC and Yi XY 2009. Remediation of soil co-contaminated with pyrene and cadmium by growing maize (Zea mays L.). Int. J. Environ. Sci. Technol. 6(2): 249-258.

Zhuang P, Yang QW, Wang HB and Shu WS 2007. Phytoextraction of heavy metals by eight plant species in the field. Water Air Soil Pollut. 184(1-4): 235-242.

(Manuscript received on 24 July, 2018; revised on 11 November, 2018) 